\title{
PERKEMBANGAN PSIKOSOSIAL ANAK DAN REMAJA PASCA ERUPSI SINABUNG DI KABUPATEN KARO
}

\author{
Wardiyah Daulay $^{1}$, Mahnum Lailan Nasution ${ }^{2}$, Sri Eka Wahyuni ${ }^{3}$ \\ ${ }^{1,2,3}$ Fakultas Keperawatan Universitas Sumatera Utara, Indonesia \\ email: wardiyah.daulay@usu.ac.id
}

\begin{abstract}
The eruption of Mount Sinabung is a natural disaster that occurred in Batukarang Village, Payung District, Karo Regency. In addition to physical conditions, this disaster affected the psychosocial condition of the community, especially children and adolescents. As a result of disasters, children and adolescents experience anxiety, stress, fear, PTSD, depression, etc. These symptoms can affect the development of adolescents themselves. This study aims to determine the psychosocial development of children and adolescents after the Sinabung eruption. Descriptive research design with a sample of 94 school-age children and 94 adolescents. The sampling technique is purposive sampling. The results showed that the psychosocial development of school-age children was in good category as many as 6 children (6.4\%), and sufficient psychosocial development was 88 children (93.6\%). While the psychosocial development of adolescents $81.9 \%$ experienced sufficient psychosocial development, $18.1 \%$ adolescents experienced good psychosocial development. The results of this study can assist mental nurses in providing psychological and social support after a disaster with a mental nursing approach so that the psychosocial development of disaster victims, especially adolescents, goes well and can improve the mental health of disaster victims.
\end{abstract}

Keywords: psychosocial development, children, adolescents, post-eruption

\section{LATAR BELAKANG}

Anak dan remaja merupakan generasi penerus bangsa sebagai sumber daya manusia pada masa yang akan datang. Kualitas bangsa di masa depan ditentukan oleh kualitas anak-anak saat ini. Anak usia sekolah sering disebut sebagai periode peralihan antara masa pra sekolah dengan masa remaja. Pada kondisi ini akan terjadi banyak perubahan pada diri anak usia sekolah, baik kondisi fisik, mental, sosial, serta terjadi peningkatan kemampuan dan keterampilan terutama keterampilan motorik. Masalah perkembangan anak merupakan hal yang perlu mendapat perhatian serius, khususnya terkait dengan perkembangan mental dan emosional atau disebut perkembangan psikososial. Perkembangan psikososial menentukan anak dalam bersikap serta mengambil keputusan di masa depan (Agustia, 2021) Anak adalah kelompok yang palingberisiko tinggi mengalami masalah- masalah psikososial. Reaksi-reaksi yang

DOI : https://doi.org/10.51544/imn.v4i2.1369

(C) 2021 Jurnal Mutiara Ners. This is an open accessarticleunder the CC BY-SA license Website : http://e-journal.sari-mutiara.ac.id/index.php/NERS/index 
muncul pada anak saat menghadapi sebuah masalah adalah menarik diri, suka mengganggu atau sulit berkonsentrasi, tingkah laku yang mundur dari tahapan usianya, misalnya menghisap ibu jari, mengompol, mimpi buruk, sulit tidur, ketakutan yang tidak masuk akal (seperti: takut gelap, takut akan segala sesuatu yang sebenarnya tidak ada), mudah tersinggung, menolak masuk sekolah, marah yang meledak-meledak, dan suka berkelahi. Terkadang ada keluhan sakit perut atau mengenai sakit lainnya. Terkadang juga mengalami rasa tertekan (depresi), perasaan bersalah,ataupun mati rasa atau emosi yang datar mengenai apapun (emosional numbness), dan cemas (Sumarno, 2013).

Pada remaja, masalah psikososial seperti pada anak usia sekolah dapat juga terjadi. Remaja merupakan masa transisi/peralihan dari masa kanak-kanak menuju masa dewasa yang ditandai dengan adanya perubahan aspek fisik, psikis, dan psikososial (Dariyo, 2004). Jika dilihat dari perkembangan psikososial menurut Erikson masa remaja merupakan masa pencarian identitas diri. Pada masa ini remaja akan menghadapi masa krisis, masalah yang berkaitan dengan tugas perkembangan yang harus dilaluinya. Keberhasilan menghadapi krisis akan mengembangkan kepercayaan dirinya, berarti mampu mewujudkan jati dirinya (self identity) sedangkan kegagalan dalam menghadapi krisis remaja akan mengalami identity confusion atau kebimbangan identitas diri (Erikson, 1968 dalam Santrock, 2003).

Berdasarkan hasil penelitian (Hartini, 2011). Pasca tsunami terjadi perubahan perilaku pada remaja di NAD.Kebanyakan remaja lebih memilih untuk bekerja di sektor pembangunan dari pada meneruskan sekolahnya karena upah kerja yang tinggi. Para orangtua juga mendukung anak mereka untuk bekerja demi memenuhi kebutuhan hidup. Dari penelitian tersebut dapat disimpulkan bahwa terjadi perubahan perilaku remaja dan kegagalan pembentukan identitas diri remaja sebagai pelajar akibat perubahan lingkungan pasca tsunami di NAD. Perubahan perilaku remaja pasca tsunami dapat ditinjau dari sebuah stresor, salah satu stressor dari kejadian negatif adalah bencana (Corner, 1995 dalam Hartini, 2011).

Salah satu bencana alam yang terbesar pada tahun 2010 yang terjadi di Sumatera Utara adalah erupsi Gunung Sinabung. Gunung Sinabung tercatat beberapa kali meletus dari tahun 2010 sampai 2015. Erupsi Gunung Sinabung mengakibatkan kerusakan dan korban jiwa. Letusan terbesar terjadi awal tahun 2014, peningkatan aktivitas gunung Sinabung dengan letusan yang berkali-kali di sertai luncuran awan panas, guguran lava pijar, semburan awan panas, rentetan gempa, letusan, dan luncuran awan panas terusmenerus dari kejadian tersebut mengakibatkan 21 desa harus diungsikan dan jumlah korban jiwa mencapai 17 orang (Ginting, 2012). Seiring denganpenurunan aktifitas sinabung beberapa desa telah dipulangkan kembali ke desanya yang berada di luar radius lima kilometer dari daerah yang berbahaya. Pada tanggal 18 September 2014 jumlah pengungsi sebanyak 5.546 jiwa dengan rincian 1.721 kk (Karo, 2014). Salah satu desa yang terkena dampak erupsi Sinabung adalah desa Batukarang yang terletak $7 \mathrm{~km}$ dari gunung Sinabung, dengan jumlahpenduduk \pm 6500 jiwa penduduk dengan rincian anakanak \pm 1.250 jiwa, remaja \pm 1500 jiwa, dewasa \pm 3000 jiwa, dan lansia

\pm 700 jiwa. Berdasarkan laporan dari 
Kepala Desa Batukarang tidak sedikit warga yang memilih untuk mengungsi dengan alasan merasa takut jika tinggal dirumah.

Berdasarkan hasil survei awal dan hasil wawancara yang telah dilakukan peneliti terhadap beberapa anak sekolah di Desa Batu Karang menyatakan bahwa "takut gunungnya meletus lagi, takut dengar suara gunungnya, kasihan orang tua tidak bisa ke ladang, tanam-tanaman rusak semua, takut pergi main-main". Sedangkanuntuk remaja di Desa Batukarang, beberapa remaja mengatakan bahwa mereka sangat ketakutan jika mendengar gemuruh dari gunung, takut jika gunung erupsi kembali dan mengeluarkan lahar panas, sebahagian remaja memilih untuk tetap berada dalam rumah dan tidak melakukan aktifitas di luar rumah seperti membantu orang tua mereka ke lahan perkebunan dengan alasan agar tidak terpapar debu vulkanik yang mengganggu saluran pernapasan mereka.

Terjadinya erupsi yang terus menerus akan menyebabkan stessor bagi anak dan remaja sehingga perlu dilakukan penelitiansebagai upaya untuk mendeteksi awal dan menurunkan angka gangguan perkembangan psikososial pada tahap perkembangan selanjutnya. Penelitian sejenis sudah pernah diteliti akan tetapi pada kondisi erupsi belum pernah dilakukan penelitian.

\section{METODE PENELITIAN}

Metode penelitian menggunakan desain deskriptif yaitu penelitian untuk mendapatkan gambaran mengenai perkembangan psikososial remaja pasca erupsi Sinabung di Desa Batukarang Kecamatan Payung Kabupaten Karo. Jumlah sampel 94 orang anak dan remaja yang berada di Desa Batukarang. Teknik pengambilan sampel adalah purposive sampling. Kuesioner yang digunakan disusun sendiri oleh peneliti yang sudah tervalidasi dan sudah melalui uji reliabilitas dengan uji cronbach alpha. Analisa deskriptif dilakukan untuk mendapatkan data dan disajikan dalam bentuk distribusi frekuensi.

\section{HASIL PENELITIAN DAN PEMBAHASAN}

\section{Perkembangan Psikososial Anak Usia Sekolah Pasca Erupsi Sinabung}

Hasil penelitian terhadap perkembangan psikososial anak usia sekolah di Desa Batukarang, secara keseluruhan menunjukkan hasil bahwa sebanyak 6 anak $(6,4 \%)$ memiliki perkembanganpsikososial baik, sebanyak 88 anak $(93,6 \%)$ memiliki perkembangan psikososial cukup, dan perkembangan psikososial kurang tidak ada. Artinya perkembangan psikososial anak di Desa Batukarang sebagian besar cukup dan ada beberapa anak yang memiliki perkembangan psikososial baik.

Tabel 1. Perkembangan Psikososial Anak dan Remaja

\begin{tabular}{|c|c|c|}
\hline $\begin{array}{l}\text { Perkembangan } \\
\text { Psikososial }\end{array}$ & $\mathbf{N}$ & $\%$ \\
\hline Baik & 6 & 6,4 \\
\hline Cukup & 88 & 93,6 \\
\hline Kurang & 0 & 0 \\
\hline
\end{tabular}

Perkembangan psikososial meliputi perubahan dan stabilitas dalam kepribadian dan hubungan seseorang (Perry \& Potter, 2009). Adanya beberapa hambatan atau gangguan dalam hal inilah yang disebut sebagai perkembangan 
psikososial cukup. Hal ini disebabkan oleh dampak bencana alam yaitu erupsi Sinabung pada aspek psikososial anak di Desa Batukarang.

Dampak bencana ynag ditimbulkan dapat terjadi pada aspek psikologi dan aspek sosial (Mundakir, 2009). Dampak bencana pada aspek fisik seperti susah tidur, perubahan nafsu makan, mudah terkejut, cepat lelah badan terasa tegang. Pada aspek psikis seperti mudah marah, dendam, rasa bersalah, malu, tidak percayadiri, gelisah, konsentrasi menurun, menarik diri, mengingat hal-hal yang tidak menyenangkan, terus menerus memikirkan sesuatu, daya ingat berkurang,menurunnya kemampuan untuk mengambil keputusan. Pada aspek sosial seperti hubungan dengan keluarga kurang harmonis, hubungan emosional juga terganngu (Mundakir, 2009).

Masalah yang terjadi pada perkembangan anak pada populasi normal di masyarakat adalah $10 \%$ dan akan meningkat ketika disertai dengan faktor risiko lain, salah satunya adalah bencana (Kar et al, 2007). Bencana seperti gempa bumi, tsunami, dan banjir merupakan faktor yangmenyebabkan tingginya tingkat stress dan masalah psikososial lainnya pada individu (Nasir et al, 2012).

Anak-anak korban bencana alam cenderung menjadi bergantung pada orang lain dan disisi lain menjadi lebih tidak percaya. Hal ini disebabkan karena rasa cemas dan tidak aman mereka akibat bencana dan kondisi paska bencana. Rasa cemas dan tidak aman ini menyebabkan beberapa anak menjadi lebih meniliai dan waspada, lebih mudah merasa ditolak dan diabaikan, serta menarik diri. Beberapa anak lainnya menjadi mudah tersinggung, terlibat konflik atau berkelahi. Hal ini akan membawa anak-anak pada kondisi tingkat stress psikososial yang tinggi dan memiliki resiko terhadap gangguan pengembangan psikologis (Sidabutar et al, 2003 dalam Wuri dan Halim, 2008).

Hasil penelitian menunjukkan bahwa62,8\% anak menghormati otoritas orang tuanya, $80,9 \%$ tanggap terhadap sekelilingnya, $74,5 \%$ anak dapat bekerja sama dengan orang lain, 64,9\% anak akur dengan saudaranya, $70,2 \%$ anak dapat berkonsentrasi baik di sekolah. Penelitian ini sejalan dengan Ningsih (2013) yang menyebutkan bahwa hubungan dengan orang tua juga merupakan dasar bagi perkembangan psikososial anak, karena pada masa anak usia sekolah akan terjadi peningkatan kemampuan dalam berbagai hal, termasuk interaksi dan prestasi belajar untuk menghasilkan suatu karya berdasarkan kemampuan diri sendiri. Pencapaian kemampuan ini akan membuat dirinya bangga. Hambatan atau kegagalan untuk hal tersebut menyebabkan anak merasa rendah diri, sehingga pada masa dewasa akan mengalami hambatan dalam bersosialisasi.

Hubungan yang baik antar orang tua dan anak dipengaruhi oleh usia orang tua, keterlibatan orang tua, pendidikan orang tua, pengalaman sebelumnya dalam mengasuh anak, hubungan suami istri, dan stress orang tua (Duvall, Evelyn, 2003).

\section{Perkembangan Psikososial Remaja Pasca Erupsi Sinabung}

Hasil penelitian menunjukkan bahwa perkembangan psikososial yang dialami remaja di Desa Batukarang pasca erupsi gunung Sinabung mayoritas mengalami perkembangan psikososial cukup yaitu sebanyak 77 responden (81,9\%). Sebahagian remaja masih mengalami trauma pasca erupsi gunung Sinabung 
seperti tidak bisa mengontrol diri saat marah 50(53\%), sering merasa sangatsedih $42(44,7 \%)$, mudah menangis setelah bencana $27(28,7 \%)$,sering merasa bersalah setelah bencana $22(23,4 \%)$, menjadi sangat ketakuatan 22(23\%) akibat erupsi gunung sinabung yang terus beraktivitas sampai saat ini hal tersebut tentunya beresiko terhadap perkembanganpsikososial remaja.

Hal tersebut sesuai dengan penelitian yang dilakukan oleh Astuti (2012) tentang pengalaman traumatik remaja perempuan akibat banjir lahar dingin pasca erupsi gunung Merapi menyatakan bahwa peristiwa traumatik di alami oleh semua sampel penelitian akibat banjir lahardingin pasca erupsi gunung Merapi hal ini menimbulkan rasa takut, cemas dan rasa sedih yang berdampak pada psikologis remaja tersebut sehingga remaja mengalami kesulitan tidur, stress, dan ketakutan yang berkepanjangan dan diikuti dengan gejala akut seperti mimpi buruk, dan ingatan terhadap peristiwa traumatik yang di alami nya dampak ini tentunya dapat mempengaruhi proses tumbuh kembang remaja dalam mencapai identitas dirinya

Menurut Davidson \& Neale (1996) kejadian traumatis dapat menyebabkan individu yang mengalami kejadian traumatisnya atau tidak bisamenghilangkan kejadian traumatisnyameski sudah lampau sehingga berkurangnya respon terhadap dunia luar seperti minat untuk melakukan aktifitas,merasa asing terhadap orang lain, efek depresif (murung, sedih, putus asa), mimpiburuk, mimpi kejadian traumatisnya secara terus menerus atau mengalami gangguan tidur, mudah marah, kesulitan konsentarsi, merasa waspada, terkejut dan ketakutan yang berlebihan.
Menurut Erikson, setiap remaja pada dasarnya dihadapkan pada suatu krisis yang berhubungan dengan tugas perkembangannya. Keberhasilan menghadapi krisis akan meningkatkan dan mengembangkan kepercayaan dirinya, berarti mampu mewujudkan jati dirinya sehingga remaja merasa siap untuk menghadapi tugas perkembangan berikutnya dengan baik, dan sebaliknya, individu yang gagal dalam menghadapi suatu krisis cenderung akan memiliki kebingungan identitas. Individu yang mengalami kebingungan identitas ditandai dengan adanya perasaan tidak mampu, tidak berdaya, penurunan harga diri, dan tidak percaya diri, akibatnya ia pesimis menghadapi masa depannya.

Dari hasil penelitian dapat dilihat bahwa remaja pasca bencana tetap memiliki hubungan sosial yang mayoritas baik yaitu hubungan dengan orang tua 61(64,9\%), hubungan dengan saudara kandung $53(56,5 \%)$, dan hubungan dengan teman sebaya $54(57,4)$, mendengarkan orang lain dan menghormatinya 51(54,3\%). Hasil ini sesuai dengan hasil penelitian (Setyaningrum, 2007). Pada penelitian ini semua sampel mempunyai hubungan yang baik dengan orangtua dan sosialnya pasca gempa bumi di daerah istimewa Yogyakarta. Hasil ini juga sejalan dengan penelitian Pratiwi(2004) kemampuan sosial anak pengungsi timor-timur termasuk dalam kategori tinggi $88 \%$ mereka tetap menjalin interaksi yang baik dengan teman dan saudaranya ditempat pengungsian dan di luar tempat pengungsian.

\section{KESIMPULAN DAN SARAN}

Perkembangan psikososial anak dan remaja pasca erupsi gunung Sinabung mayoritas responden mengalami 
perkembangan psikososial dalam kategori cukup.

Disarankan kepada perawat jiwa berkomitmen memberikan dukungan secara psikologis dan sosial kepada anak dan remaja pasca bencana secara cepat untuk mengantisipasi dampak psikososial pasca bencana.

\section{DAFTAR PUSTAKA}

Agustia. D.R. (2021). Perkembangan Psikososial Anak Usia 3-4 Tahun di Daycare. Aulad : Journal on Early Childhood. Vol 3 No 3, Pages 149-154

DOI: 10.31004/aulad.v3i3.75

Arfianti. (2011). Gambaran Tingkat Distress Psikologis Satu Tahun Pasca Trauma healing Akibat Gempa Bumi Pada Siswa Kls III,IV, dan V SDN Kota Padang Thn 2011.

Skripsi. Fakultas

Keperawatan Universitas Andalas Padang

Astuti, R.T. (2012). Pengalaman Traumatic Remaja Perempuan Akibat Banjir Lahar Dingin Pasca Erupsi Gunung Merapi Dalam Perspektif Tumbuh Kembang Di Hunian Sementara Kabupaten Magelang. Tesis.

Dariyo, A. (2004). Psikologi Perkembangan Remaja. Bogor : Ghalia Indonesia

Durkin. (1993). The Effects of A Natural Disaster on Child Behavior: Evidence for Post traumatic Stress

102

DOI : https://doi.org/10.51544/imn.v4i2.1369

(C) 2021 Jurnal Mutiara Ners. This is an open accessarticleunder the CC BY-SA license Website : http://e-journal.sari-mutiara.ac.id/index.php/NERS/index
Diakses melalui /pm/Articles/pmc/1694881/pdf/Amj ph0535 0039.pdf.

Hartini, N. (2011). Remaja Nangroe Aceh Darussalam Pasca Tsunami. Journal Universitas Airlangga volume $24,45-51$.

Kar (2011). Psychological Impact of Disaster on Children: Review of Assessment And Interventions http://www.wjpch.com/uploadfile 9$\underline{005 . p d f}$

Mundakir. (2009). Dampak Psikososial Akibat Bencana Lumpur Lapindodi Desa Pajarakan Kecamatan Jabon Kabupaten Sidoarjo. Depok: FIK UI.

Potter \& Perry. (2009). Buku Ajar Fundamental Keperawatan. Jakarta : EGC.

Santrock, John W. (2003). Adolescence Perkembangan Remaja. Jakarta:Erlangga. http://Www.Ncbi.Nim.Nih.Gov/ 